\title{
APPLICATION OF REMOTE-SENSING TECHNIQUES TO THE STUDY OF SEASONAL SNOW COVER
}

\author{
By Mark F. Meier \\ (U.S. Geological Survey, Tacoma, Washington 98402, U.S.A.)
}

\begin{abstract}
This paper discusses the measurement of important snow properties using electromagnetic radiation. Snow areal extent can be measured using manual, optical, electronic, or digital techniques from data supplied by visible and near-visible light sensors carried on Earth resources and meteorological satellites, but these techniques cannot routinely detect snow under clouds or a forest canopy. Gamma-ray techniques used at stations or from low-flying aircraft permit measurement of water equivalent of snow (depth times density). Active or passive microwave systems may permit this to be done over larger areas, but the physics of this possible technique is not yet sufficiently understood. Wetness or temperature of a snow surface is measurable with thermal infrared radiometers; wetness throughout a snow pack may be measurable with microwave radiometers. Much research needs to be done on the electrical (including scattering) properties of snow before efficient, all-weather, remote-sensing systems can be designed.
\end{abstract}

RÉsumé. Application des techniques de télédétection a l'étude du manteau neigeux saisonnier. L'article traite de la mesure des propriétés importantes de la neige à l'aide de radiations électromagnétiques. L'extension de l'enneigement dans l'espace peut être mesurée par des techniques manuelles, optiques, électroniques ou digitales à partir des données fournies par des capteurs en lumière visible ou proche du visible portés par des satellites météorologiques et de prospection de ressources terrestres; mais ces techniques ne peuvent pas habituellement détecter la neige sous les nuages ou à travers un couvert forestier. Des techniques de gammamétrie utilisées en sol ou à partir d'un aéronef volant à basse altitude permettent de mesurer l'équivalent en eau du manteau neigeux (produit de l'épaisseur par la masse volumique). Des systèmes actifs ou passifs sur courtes longueurs d'ondes peuvent permettre une extension sur des surfaces plus importantes, mais la physique de ces techniques possibles n'est pas encore assez bien comprise. L'humidité ou la température de la surface de la neige est mesurable avec un radiomètre à infrarouge calorifique; l'humidité à l'intérieur du manteau neigeux peut être mesurable grâce à des radiomètres à faible longueur d'onde. Il faut encore beaucoup de recherches sur les propriétés électroniques (y compris la dispersion) de la neige avant qu'on puisse proposer un système de télédétection de la neige efficace par tous temps.

Zusammenfassung. Anwendung von Fernerkundungsmethoden für das Studium der jahreszeitlichen Schneedecke. Die Arbeit handelt von der Messung wichtiger Schneeeigenschaften mit Hilfe elektromagnetischer Strahlung. Das Ausmass der Schneebedeckung kann manuell, optisch, elektronisch oder digital aus Daten bestimmt werden, die von Sensoren für sichtbares oder fast sichtbares Licht in Erderkundungs- und meteorologischen Satelliten geliefert werden; doch ist mit dieser Methode Schnee unter einer Wolkendecke oder einem Waldkleid routinemässig nicht festzustellen. Verfahren mit Gammastrahlen, angewandt von festen Stationen oder aus niedrig fliegenden Flugzeugen, ermöglichen Messungen des Wasseräquivalents von Schnee (Höhe mal Dichte). Mit aktiven oder passiven Mikrowellensystemen könnten diese Messungen auf grössere Gebiete ausgedehnt werden, doch ist die Physik dieses möglichen Verfahrens noch nicht ausreichend bekannt. Wassergehalt und Temperatur einer Schneeoberfläche lassen sich mit thermischen InfrarotRadiometern messen; die Feuchte innerhalb einer Schneedecke könnte mit Mikrowellen-Radiometern erfassbar sein. Viele Untersuchungen über die elektrischen Eigenschaften des Schnees (einschliesslich der Streuung) müssen noch vorgenommen werden, bevor wirksame, wetterunabhängige Fernerkundungssysteme entworfen werden können.

\section{THE PROBLEM}

Seasonal snow can be characterized as a widespread, granular, layered material which is thermodynamically unstable, extremely variable in time and space, and which has rather unique electromagnetic properties. Snow covers - at least for most of the year - virtually all other materials of glaciological interest. A layer thousands of square kilometres in extent may be emplaced in hours, or removed by melting just as rapidly. Snow on the ground is continually subjected to a changing thermal environment so its physical properties change constantly; snow is easily eroded and redeposited by the wind so its thickness distribution also undergoes change. In order to monitor the seasonal snow cover, or to understand its changes in time and space, a synoptic view may be required and this requires remote sensing.

Most remote sensing is performed using electromagnetic radiation, and the electrical properties of snow are very interesting. Snow is highly reflective (white) in the visible region of the spectrum, highly absorptive (black) in the thermal infrared region, and ranges from 
gray and nearly opaque to virtually transparent at longer wavelengths. When snow warms to the melting temperature, liquid water appears, and this causes a large change in its electrical properties, especially at longer wavelengths. Because snow has such a diverse response to electromagnetic radiation, the possibilities of monitoring it by remote sensing would appear to be good.

Monitoring of snow packs - whether for prediction of avalanches, forecast of snow-melt run-off, determination of the mass balance of glaciers, or for other practical or scientific purposes-requires measurement of several snow properties. These usually include areal extent, depth, and density (or the product of depth times density, termed "water equivalent"), free moisture (liquid-water content), and temperature. Other properties, such as layered structure or grain size, may be important for some applications. In general, variations in these properties with time and space need to be recorded. Spatial variations of interest range in scale from profiles through a snow pack at a research site, to local area or drainage basin observations, to regional or even global surveys. Remote-sensing techniques offer exciting possibilities for monitoring the changes in snow properties with time and at all spatial scales.

This paper will attempt to describe some of the more important remote sensing techniques which have been considered for the measurement of the different properties of snow, and to point out some of the potential applications or limitations of these techniques. Discussion will be confined to remote sensing by electromagnetic waves. The parts of the electromagnetic spectrum considered here include gamma rays (wavelength $10^{-12} \mathrm{~m}$ ), visible and nearinfrared $\left(10^{-6} \mathrm{~m}\right)$, thermal infrared $\left(1 \mathrm{O}^{-5} \mathrm{~m}\right)$, and microwave $\left(1 \mathrm{O}^{-3}\right.$ to $\left.\mathrm{IO}^{-1} \mathrm{~m}\right)$.

\section{Areal Extent of SNOW cover}

Snow properties can be measured with relative ease at stations, but no operational method exists for monitoring snow over large areas. Knowledge of just the areal extent - the position of the snow line- over large areas and at frequent times would be enormously helpful to many users of snow data. Fortunately, remote-sensing techniques show potential for accomplishing this task, and much research work has been devoted to this.

Frequencies in the visible wavelength region have been used for many years to measure snow either from aerial photographs or more recently from satellite images (Fritz, I962; Barnes and Bowley, I968). Meteorological satellites, such as the METEOR or NOAA series, pass over given areas on Earth at least once a day so that the rate of image acquisition is high. The same can be said of the synchronous satellites which may continuously image most of one hemisphere of the earth. However, none of these satellites has sufficient resolution to identify small snow patches or snow in forested areas nor do they present images which can be directly related to conventional map projections, and the synchronous satellites do not show much data beyond about $50^{\circ}$ latitude.

The Earth Resources Technical Satellite (ERTS) represents the first of a new generation of satellites which have very great potential. The ERTS-type satellites have several important advantages: high resolution (Fig. I), accurate map projection, and multispectral data allowing use of pattern-recognition techniques. However, these advantages are gained at the expense of frequent coverage; the ERTS satellite passes over a given spot on Earth only once in $18 \mathrm{~d}$.

Images such as those produced by ERTS can be processed in many ways. For instance, snow-covered area can be obtained by radiance slicing (selecting the appropriate shade of gray to define the snow/no-snow boundary), radiance-gradient slicing, time-lapse comparison (for instance, comparing portions of the same image in a snow-free and snow-covered condition, or successive snow-covered images), and by multispectral analysis. The snow cover in a mountain region can also be approximated by the snow-line altitude which can be determined by direct measurement on a topographic map (Fig. 2), by the variable contour overlay 


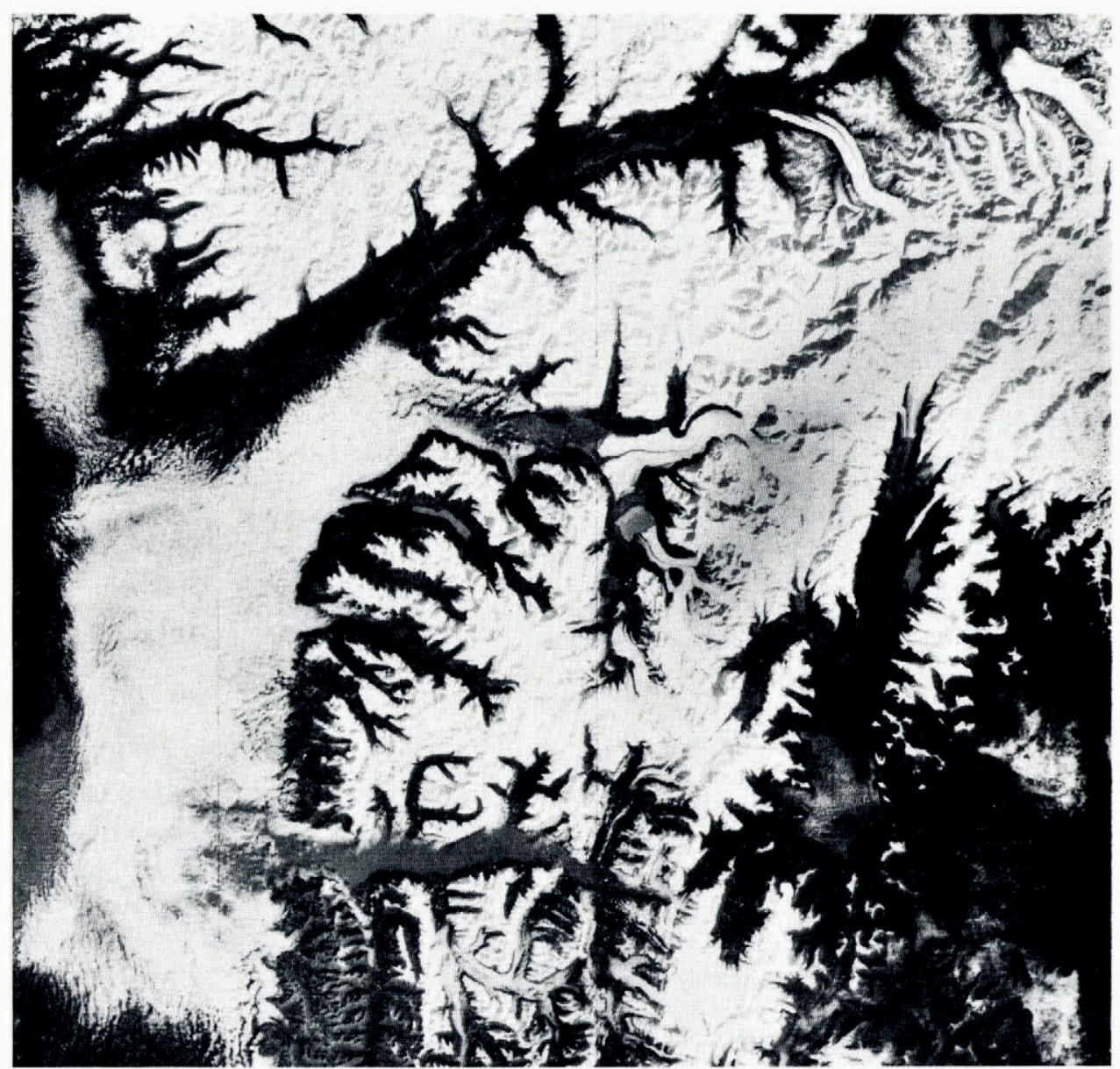

Fig. I. ERTS image of the Anchorage and Western Chugach Mountain area showing a clearly definsd snow line. Fog lies in the Cook Inlet lowlands on the left. ERTS image No. 1066-2045-4, 27 September 1972.

method (cycling through a sequence of masks which are cut to the shape of successive topographic contours), or by using the area measurement and relating this to an area/altitude diagram of a drainage basin or mountain and from that determining the equivalent snow-line altitude (ESA) (Fig. 3).

Most of these techniques can be used at at least three levels of sophistication: from manual and optical techniques based almost entirely on the human eye (Barnes and Bowley, 1973) to interactive consoles such as the Electronic Satellite Image Analysis Console (ESIAC) in which the operator retains an important interactive role with electronic or digital processing (Evans and Serebreny, 1973; Meier, I973[a]), or by purely digital processing. The amount of data fed to Earth by the newer satellites can swamp a person's capability to do manual or optical analyses. Thus electronic console or digital processing systems are needed to perform measurements rapidly and with useful accuracy. All-digital processing is ideal for very accurate radiance slicing, radiance-gradient slicing, or multi-spectral (pattern-analysis) techniques. Although purely digital analysis has many important advantages over those techniques which use the human eye in operation, it is not yet possible to differentiate clouds from snow on any 


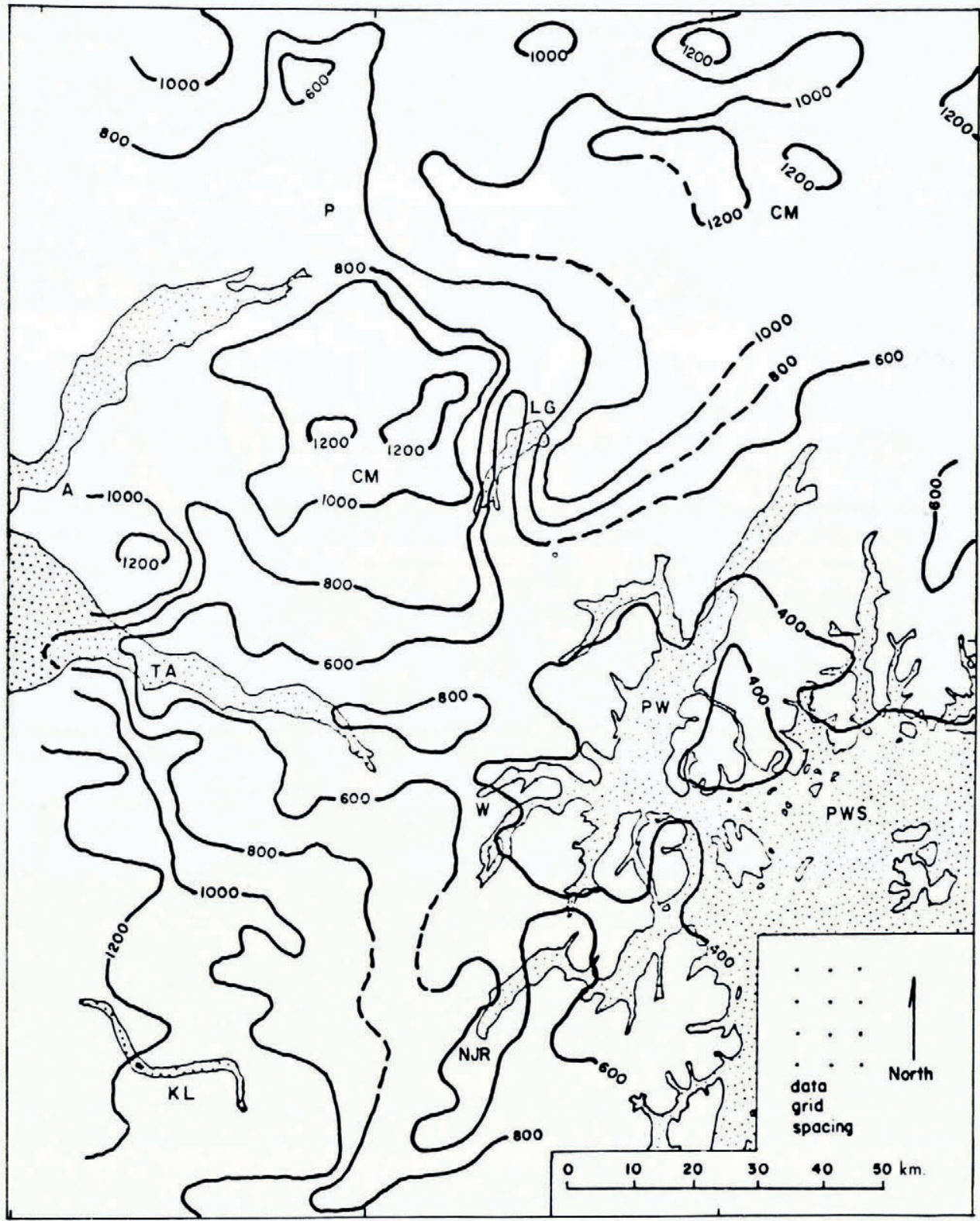

Fig. 2. Map of the altitude of the snow line in the same general area and obtained from the same image as Figure 1 . Locations are as follows: P-Palmer, CM-Chugach Mountains, LG-Lake George, A-Anchorage, TA-Turnagain Arm, $W$-Whittier, PW-Port Wells, PWS-Prince William Sound, KL-Kenai Lake, NJR-Nellie Juan River. Note the depression of the snow line, and, therefore, the freezing level in the Prince William Sound-Port Wells area and the extensions of this low-freezing level in the valleys of Turnagain Arm and Lake George. From Meier, 1973[a]. 


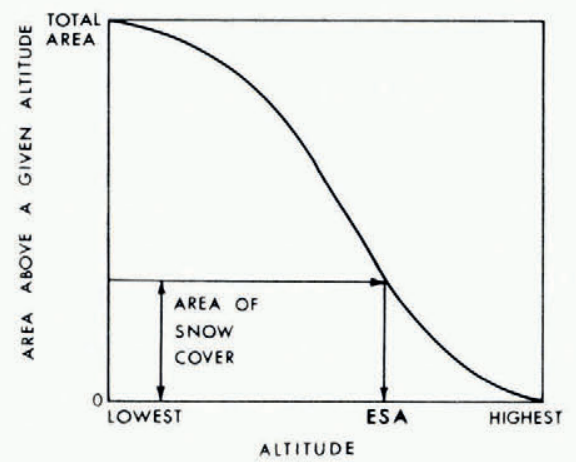

(a)
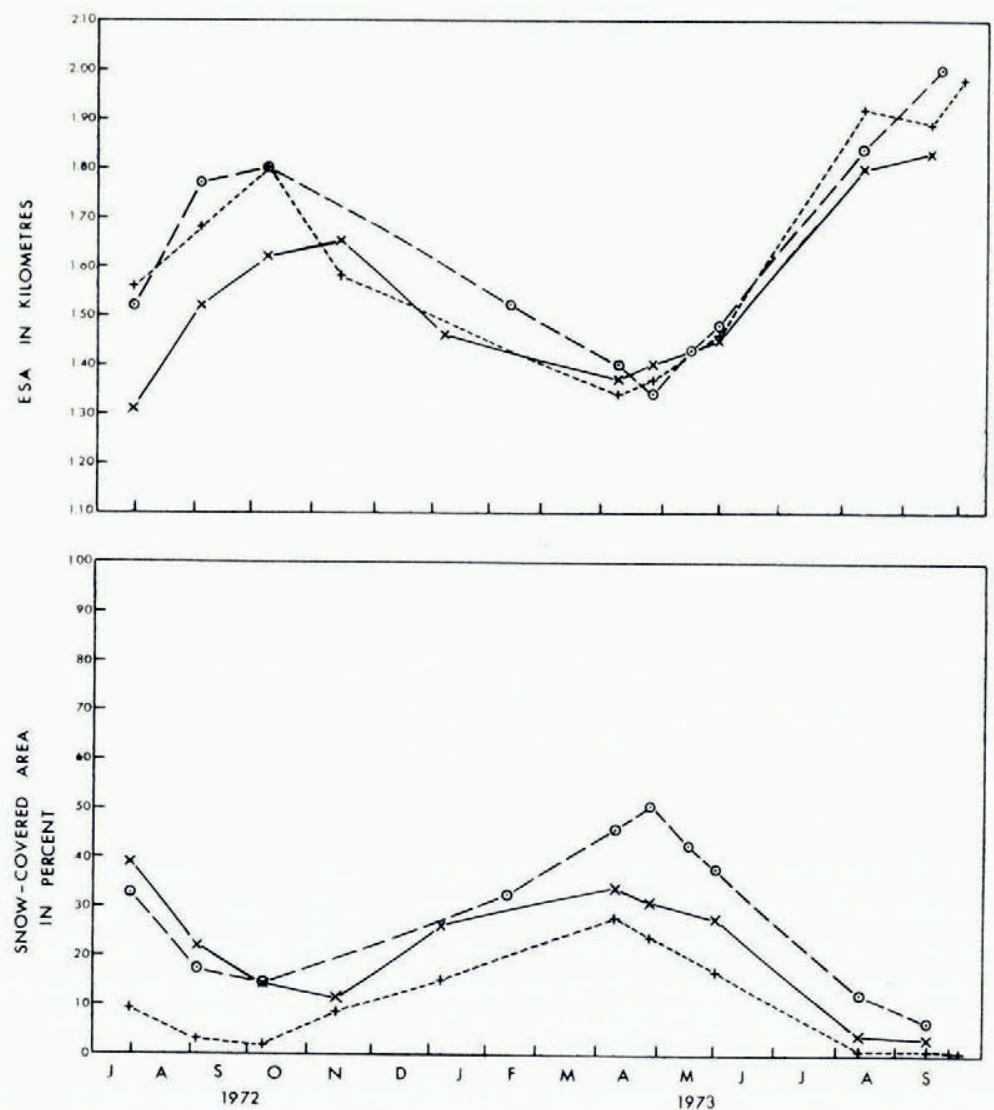

(b)

Fig. 3. (a) Diagram showing how the equivalent snow-line altitude (ESA) is obtained. (b) Values of percent of snow-covered area and ESA for three drainage basins in the North Cascades, Washington, from July 1972 to October 1973. The basin, Sauk River, is indicated with an $\times$, the Cascade River with a circle, and the South Fork of the Skykomish River with a cross. Note that the ESA varies consistently with time in these three basins. All data obtained from ERTS images analyzed on the ESIAC console. 
routine, programmable basis. Fully automatic processing of satellite imagery to obtain measurements of snow-covered area does not yet appear to be possible unless cloud-free conditions are known.

The results of measuring snow with ERTS images have been far more encouraging than originally expected. The map projection of ERTS images permits rapid comparison with drainage basin or topographic map scales of I : 250 ooo or I : I 000 ooo. The resolution of the ERTS images is also better than originally expected. Studies at South Cascade Glacier have shown that the mean resolution for snow-line determinations can be approximated by a circle $80 \mathrm{~m}$ in diameter. This means that the changes in snow-covered area in a drainage basin as small as $6 \mathrm{~km}^{2}$ can be measured easily (Krimmel and Meier, I975). Also snow patches as small as $150 \mathrm{~m}$ in maximum dimension can be identified (Meier, I974). Thus the resolution of ERTS is sufficient for almost all practical snow-mapping needs. By use of a console such as ESIAC, snow-covered areas or equivalent snow-line altitudes in specific drainage basins

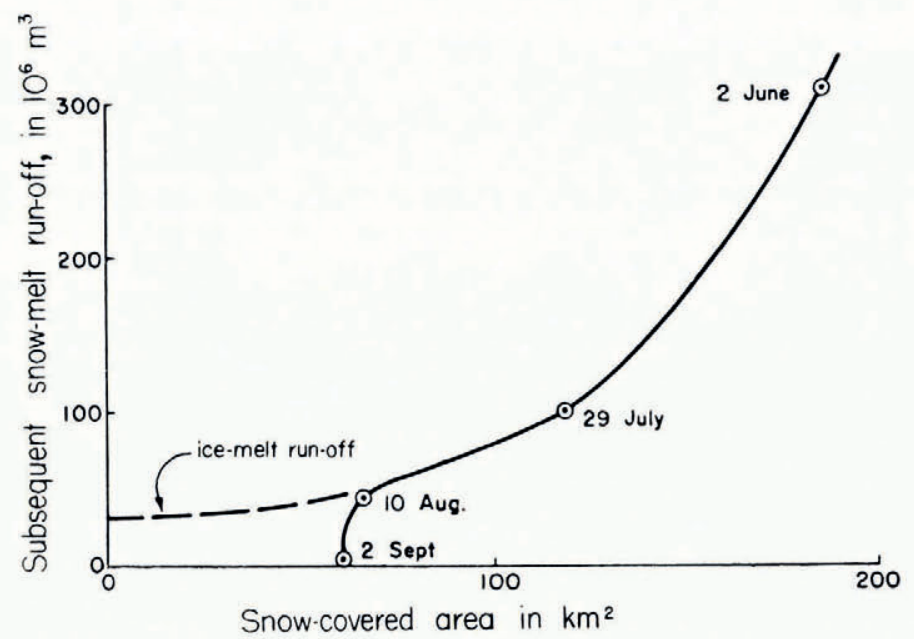

Fig. 4. Graph showing a typical curve of the depletion of snow-covered area and subsequent snow-melt run-off for the drainage basin of Thunder Creek in the North Cascades, Washington. The snow depletion curve was obtained from ERTS and high-altitude aircraft images during the melt season of 1972. By measuring snow-covered areas, one can use this function to forecast the run-3ff to follow approximately. From Meier (1973[a]).

can be determined in a matter of a minute or so per image. Through the use of these techniques the snow-line altitude and therefore the snow-cover extent can be extrapolated from one imaged basin to a nearby basin which is partly off the image or partly cloud covered. Finally, the hydrologic usefulness of these data has been shown by the construction of snowcover depletion curves (Leaf, I967; Martinec, 1973) which can be used to forecast the inflow to reservoirs (Fig. 4).

Satellite data in the visible, near-visible, and infrared wavelengths, such as those obtained by NOAA-2 or ERTS, cannot yet be used routinely or operationally to measure the areal extent of snow because of two major problems: clouds and trees. The radiances of snow and clouds usually approach saturation of visible or near-visible light sensors, the multi-spectral signatures of snow and clouds are similar, and clouds do not always have distinctive, machinerecognizable shapes. However, melting snow may appear appreciably darker than certain clouds in the near-infrared (Barnes and others, 1974). Much more data need to be obtained 
on the spectral reflectances of different types of snow and clouds before these results can be generalized. Clouds may also be distinguished from snow because the radiance of a cloudcovered spot on Earth varies with time (McClain and Baker, 1969).

In some areas, such as the Pacific Northwest of the United States, snow on the ground may be masked by a nearly continuous canopy of trees. If the canopy cover is not complete, then some radiance from snow may be detected by the satellite. In this case a multi-spectral (pattern-recognition) analysis may be able to detect areas which combine the signatures of snow and of forest cover (Fig. 5). However, if the forest canopy is completely closed, there is no possibility of detecting snow on the ground with visible or infrared wavelength sensors.

Perhaps a solution to the problem of observing the areal extent of snow through clouds lies in the use of microwave radiation. Thermal radiation from snow in the microwave wavelengths (passive microwave emission) can be detected with sensors flown in aircraft or satellites. Clouds attenuate this radiation only slightly if relatively low frequencies are used. The emission from snow (expressed as a brightness temperature in kelvins) is different from that of water or bare soil or rock. The areal extent of snow cover should be measurable in any kind of weather using microwave radiometers mounted in aircraft or satellites.

The resolution of microwave radiometers will always be coarse compared to visible light sensors such as those used on ERTS, because of limitations on antenna size. The beam width (in radians) of an antenna is approximately $\lambda / D$, where $\lambda$ is wavelength and $D$ is diameter. Assuming $D=10 \mathrm{~m}$ and $\lambda=10^{-1} \mathrm{~m}$, beam width is $\mathrm{IO}^{-2} \mathrm{rad}$ compared with $\mathrm{IO}^{-4} \mathrm{rad}$ of ERTS. However, this may not be as severe a limitation as it appears; the microwave brightness temperature of snow is so distinctive that the percentage of snow-covered area in any field of view can be calculated from the average brightness temperature observed (Meier, I973[b]).

\section{DEPTH AND DENSITY (OR WATER EQUIVALENT)}

Gamma rays, from either natural or artificial sources, are attenuated as they pass through a snow pack, and the amount of attenuation depends on the density of the snow and the path length through the snow. Thus gamma-ray attenuation can be used to measure depth, density, or the total mass (water equivalent) of a snow pack. This technique can be used at a fixed station or from a moving vehicle or aircraft.

If the radioactive source of gamma rays is buried below (or suspended above) the snow pack and the detector suspended above (or buried below), the attenuation is a direct measure of the total mass of the snow and no information is derived on the thickness or distribution of mass with depth. The source can be the natural radioactivity of the ground (Bissell and Peck, I973).

A source and detector which travel vertically through the snow inside of one or two tubes can be used to measure snow density as a function of depth (Smith, 1967). Such radioactive single or twin probes have been developed to the point where they are capable of reliable unattended operation for long periods of time and the data output can be telemetered either through telephone lines or through microwave or satellite relays to a central office (Randolph and others, 1973). The property of the snow which is directly measured by this technique is density, but this is measured as a function of depth so the water equivalent in the vicinity of the snow gage can be continuously monitored. These devices appear to have a great potential for use at snow stations to monitor continuously the most important properties of the snow pack; the major drawback is cost.

Gamma ray attenuation can be used to measure snow-pack mass along flight lines. This technique involves the measurement of natural gamma radiation by flying large scintillometers at low altitudes ( 50 to $150 \mathrm{~m}$ ) above the ground; at these altitudes most of the detected radiation originates in the bedrock or soil and is attenuated by snow. Thus the mass or water 


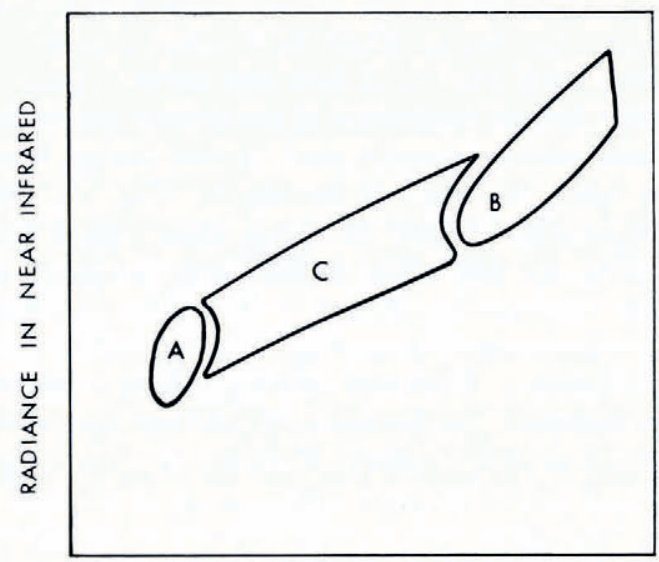

RADIANCE IN RED LIGHT

(a)

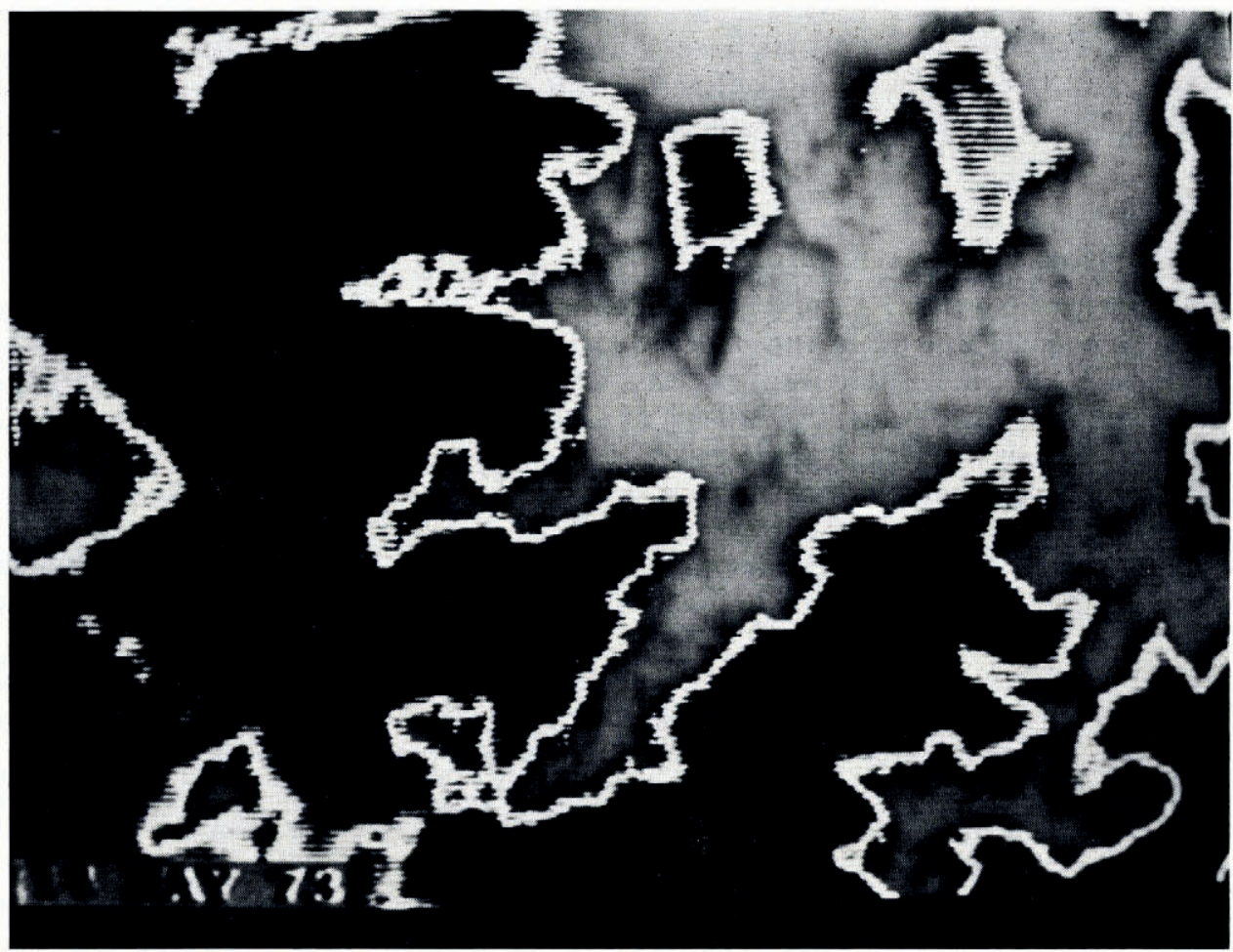

(b)

Fig. 5. (a) Diagram showing pattern or cluster analysis (color-space presentation) used to detect snow in trees. Area A is a typical response of evergreen trees. Area $B$ is a typical response of snow. A mixed snow and tree signal can only fall in area $C$. (b) ERTS images of part of the Mt Olympus area, Washington, reprocessed in accordance with a pattern analysis as shown in Figure $5(a)$. The black area represents trees, the mottled gray area is snow, and the bright area between represents a combination of radiances from both snow and trees. Thus, the approximate area of snow which is partly hidden by trees can be measured. 
equivalent of the snow cover can be integrated or averaged over the length of the flight line (Kogan and others, 1965; Peck and others, 1971; Grasty and others, 1974). However, problems still exist with the operational use of this important tool, and it is limited to measurement of snow over relatively flat lands because of the restricted flight altitude.

In order to obtain truly synoptic (large area, often repeated) monitoring of snow-pack mass, especially over mountainous areas, it will be necessary to use wavelengths at the opposite end of the electromagnetic spectrum. Microwave radiation penetrates through snowpacks, and the emission/absorption caused by the snow is related to the snow density and path length. Thus the potential for use of microwave radiation to measure snow mass is clear, but no system has yet been demonstrated that can do this. Two possible systems can be considered: active systems (radar) illuminate the snow with microwave energy and then detect the energy reflected or scattered back; passive systems record the thermal emission from the snow in the frequency range of the radiometer used.

Active systems have many inherent advantages. Through a combination of range gating and synthetic-aperture signal processing it is possible to obtain a high-resolution image even with an antenna of very broad beam width. Also the reflected signals can be processed in a

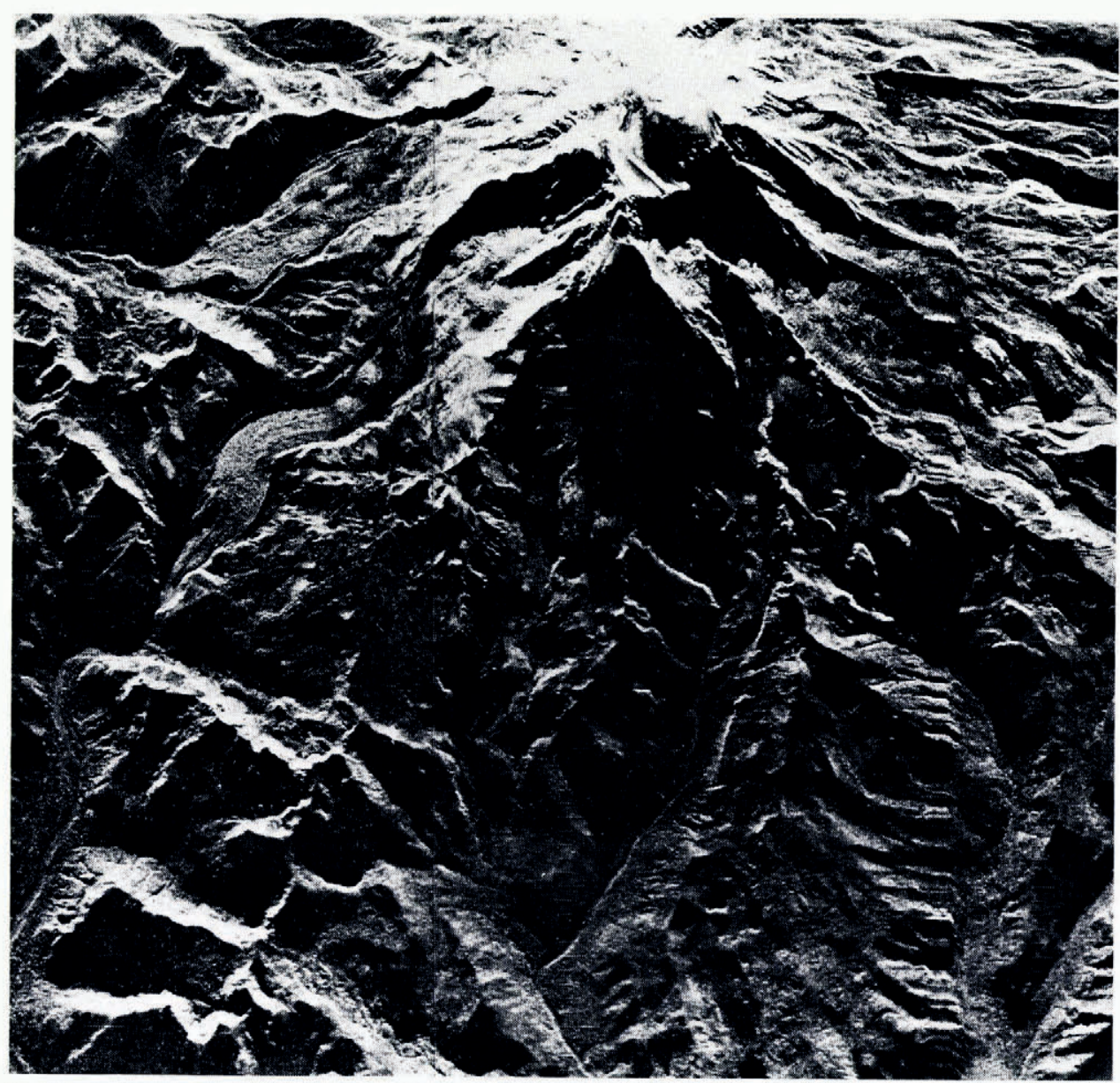

Fig. 6. Side-looking radar (SLAR) image of Mt Rainier, Washington. Although snow near the summit shows a bright return, the snow line which occurs about half-way down the mountain cannot be detected. 
number of ways to determine the characteristics of the reflecting surface or elements (Moore, 1972).

Much work has been done in Earth resources studies using side-looking airborne radar (SLAR). Unfortunately the few studies of snow which have been done yield enigmatic results. In some cases seasonal snow cannot be detected at all (Fig. 6) (Meier and others, 1966). In other situations using virtually the same equipment and similar terrains, snow may produce an extremely bright and distinctive reflection (Waite and MacDonald, 1970).

Simple short-pulse radio systems can be used to measure snow thickness or density (Vickers, 1971). Unfortunately, using just a single frequency one cannot determine both thickness and density, but if one parameter is known the other can be determined. A multi-frequency technique (Linlor, I975) does show the possibility of determining both thickness and density and therefore the water equivalent of snow and perhaps even the characteristics of a second underlying layer. However, such a system exists only in concept at this stage and the possible effects of scattering, surface roughness, gradational interfaces, etc., have yet to be evaluated.

Another technique which needs investigation is the active illumination of metal loops or wires buried under the snow. This technique might make it possible to measure the water equivalent of the snow with a fairly simple active radar.

Passive microwave techniques have been studied for many years as a method of determining snow properties from aircraft or satellites (Edgerton and others, 197I). However, the resolution of these systems is limited by the physical size of antennas. For very large snow fields, such as the accumulation area of the Greenland ice sheet, this is no problem, but microwave surveys for hydrologic applications may have to be conducted by aircraft in order to provide sufficient resolution.

The physics of microwave emission from snow is still not completely understood. Carefully controlled field experiments have shown that the microwave emission changes in a regular way as the snow pack increases from zero to the thickness of a metre or so (Meier and

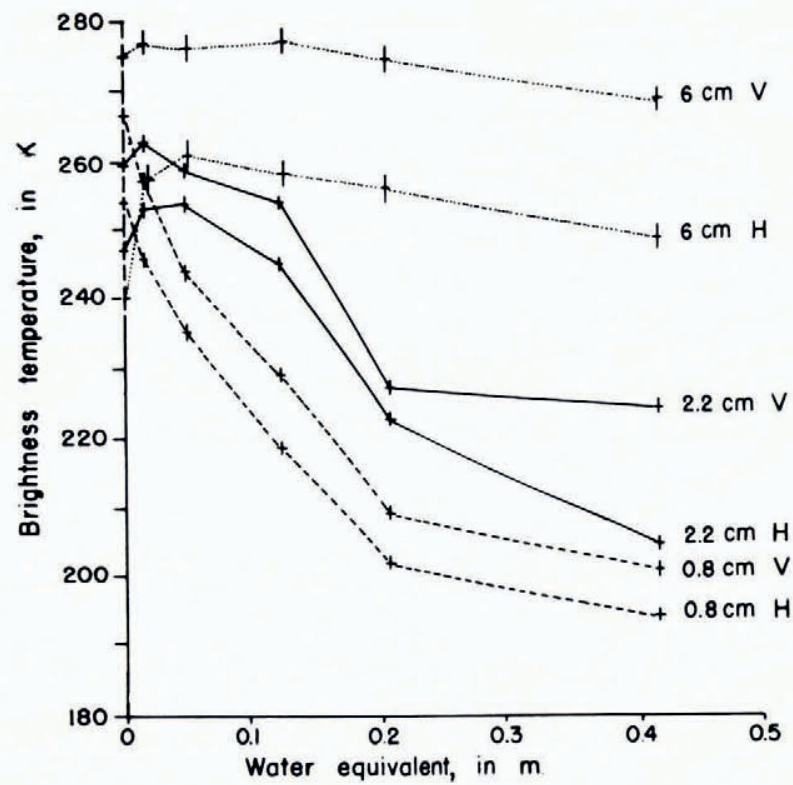

Fig. 7. Measured dry-snow brightness temperatures, taken at $45^{\circ}$ viewing angle, at three wavelengths and two polarizations ( $H=$ horizontal, $V=$ vertical polarization). Absolute values of brightness temperature at $6 \mathrm{~cm}$ wavelength are not known, but relative variations in brightness are correct. Measurement errors indicated by short dashes. Crater Lake, Oregon, 23 March 1970 . From Meier and Edgerton (I97I). 
Edgerton, I97I); thus it appears in principle that one could determine the water equivalent of snow from the microwave brightness (Fig. 7). However, the general applicability of this result is not yet established.

Recently, carefully conducted aircraft surveys of microwave emission as a function of frequency have been available (Schmugge and others, 1974). The results have been compared with numerical models for emission from a layered dielectric; the dielectric constant of dry snow is well known (Ambach and Denoth, 1972). Unfortunately the emission calculated from a simple layered dielectric (Stogryn, 1970) does not agree with the observed values. We now believe that the problem is due to volume scattering in the snow pack. It has been shown that volume scattering does cause an appreciable darkening of the microwave emission in materials which have a low dielectric constant such as snow (England, 1974). A recent recalculation of a I97 I overflight of South Cascade Glacier using a preliminary scattering theory (England, 1974) shows that scattering appears to account for the observed change in emission as a function of frequency. This point needs further examination.

Microwave emission from snow may be found to be a sensitive function of the size and spacing of scatterers, in which case microwave remote sensing would be limited to obtaining information on these scatterers (individual ice grains or ice lenses). On the other hand it may prove that snow of roughly the same density or grain size has similar scattering properties and therefore information of hydrologic value can be obtained by passive microwave sensing. The possibility of remotely measuring snow mass and other properties through any weather is so important that the problem of scattering deserves much further study.

\section{Temperature and Wetness}

These two snow properties are of primary interest to heat and water balance studies. They are considered together because the value of one property may determine the value of the other (if temperature $<0^{\circ} \mathrm{C}$, wetness $=0$, if wetness $>0$, temperature $=0^{\circ} \mathrm{C}$ ). Temperature can be measured routinely at stations through the use of thermocouples or thermistors, but liquid-water content is more difficult. It seems possible that this can be measured by microwave absorption techniques (Linlor and others, 1974). However, the ability of such a technique to obtain consistent and reliable data on liquid water is just now being tested. One of the problems with developing any system for measuring liquid water in snow is calibration. Existing physical, thermal, or electrical instruments, such as calorimeters, capacitance gages, and centrifuges, are either too inaccurate, too slow, or cannot read small enough volumes to be used routinely for calibration purposes. Development of an electrical resonance-width method has apparently solved this difficult problem (Linlor and Smith, I974) (Fig. 8) but truly portable field equipment must yet be devised. A microwave absorption probe working in conjunction with a radioactive twin probe and a temperature system would appear to provide all the necessary data that a hydrologist requires for detailed mass, water, and heat balances within snow at a single station. However, the areal variability of snow is so great that devices working from aircraft or spacecraft are vitally needed.

Thermal infrared (wavelengths 8 to $\mathrm{I} 4 \mu \mathrm{m}$ ) devices which can be flown in aircraft or satellites yield information on the surface temperature and the surface melting condition of snow, and often this provides very useful information (Barnes and Bowley, 1972). (The melting or non-melting condition of a snow surface can also be determined by comparison of the visible and near-infrared reflectivities (Strong and others, 197I).) The thermal inertia of a semi-infinite solid can be determined by the change in surface temperature during a known diurnal cycle of heating and cooling (Watson and others, 197 I); if the semi-infinite solid is a thick snow pack, the resulting thermal inertia should be related to the density or to the amount of water in the near-surface layer. Conversely, if the amount of water can be known or estimated, the surface temperature of snow as it freezes at night provides information on the 


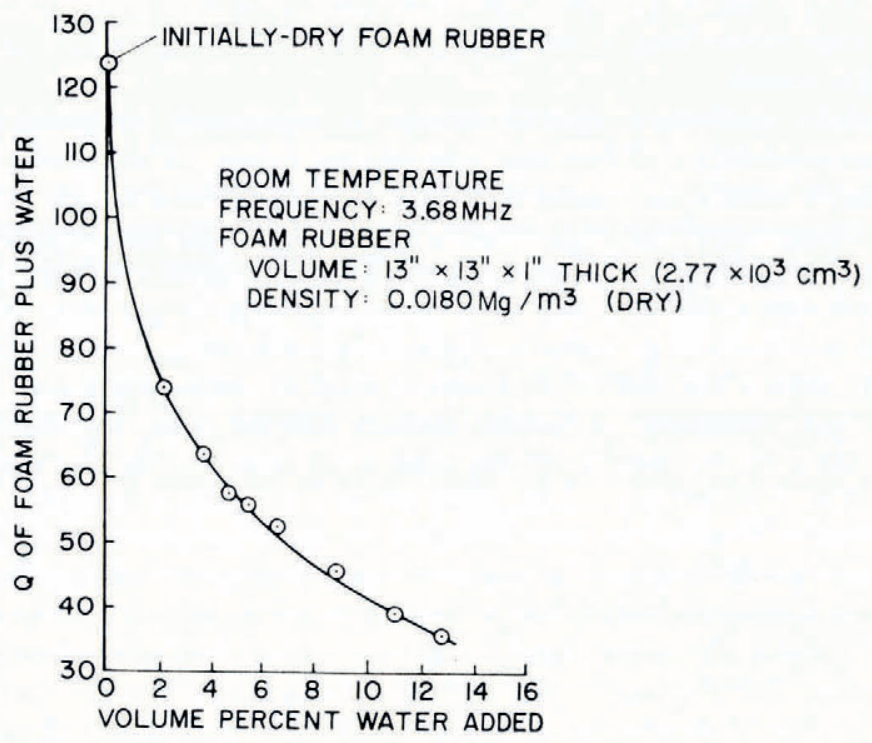

Fig. 8. Dependence of the " $Q$ " or resonance factor of foam rubber with the addition of small amounts of water. Similar results are obtained with the addition of small amounts of water to snow. However, the preliminary results using snow are not as well calibrated because of the difficulty of controlling the amount and distribution of small amounts of water in snow. From Linlor and Smith (1974).
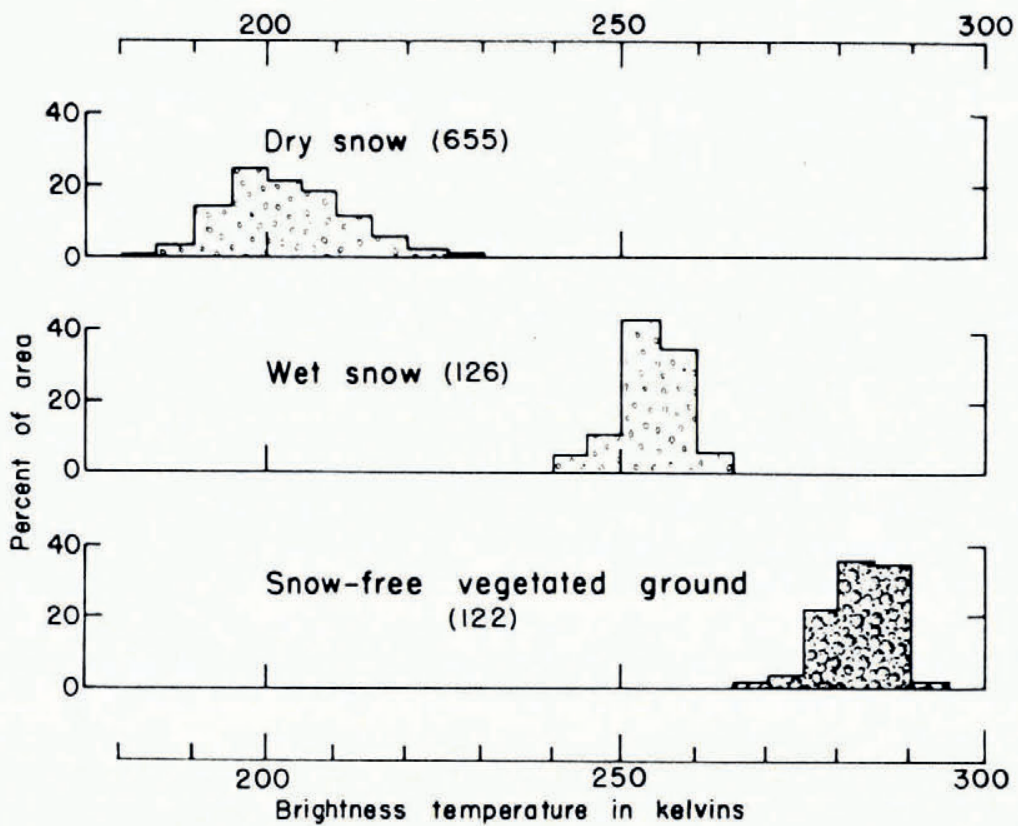

Fig. 9. Distribution of brightness temperature with area for three types of terrain in the vicinity of South Cascade Glacier, Washington. The dry-snow data were obtained 8 March 1971 ; the wet-snow and snow-free, vegetated-ground data were obtained 18 June 1963. Figures in parentheses indicate number of observations (resolution cells). From Meier (I973[b]). 
heat balance. Since this temperature can be mapped through the use of scanning radiometers it would appear that mesoscale studies of certain components of the heat balance are possible. This opens up a powerful new tool which will certainly be exploited when calibrated thermal infrared scanners are more widely available.

Unfortunately thermal infrared radiometers can only measure effects in the surface and near-surface layers of the snow. Passive microwave radiometers, on the other hand, measure properties through tens of centimetres to tens of metres of snow. The microwave emission from wet snow is markedly different from that of dry snow (Fig. 9). Thus the average wetness condition, not just the surface condition, of a snow layer could be determined using microwave radiation. Unfortunately, because of our present lack of understanding of the physics (especially volume scattering) of microwave emission, we cannot yet use this potential tool in a quantitative fashion.

\section{Problems For RESEARCH}

Many questions need to be answered before the rapidly varying snow cover can be adequately monitored by remote-sensing techniques. A new generation of Earth resources and meteorological satellites will soon be appearing. These will provide more frequent coverage, more multi-spectral channels in the visible to infrared wavelengths, and perhaps even higher resolution than any existing satellite. In order to exploit these exciting new possibilities fully, we must be able to handle the huge information flow which will be produced; thus we must turn more and more to automatic (machine) processing of the imagery. The basic research necessary for this has not yet been accomplished; we can automatically discriminate snow from wheat fields, alluvial fans, or open water, but not from clouds. We are not even sure if such a discrimination is possible. And, if we solve the problem of differentiating snow from clouds, how are we going to measure snow under a closed forest canopy? Increased research in this field is obviously necessary for short-term benefits.

In the more distant future we will require - and probably be able to obtain - an allweather capability of observing snow, and this will require active or passive microwave radiation. The physics of emission, reflection, and scattering from snow packs is not yet well known, either in theory or by empirical observation. Many questions need to be answered before a proper active or passive microwave sensing system can be designed. These include such matters as the interface and volume scattering properties of snow (what are the objects in snow which cause volume scattering?). Also, what are the dielectric and scattering properties of wet snow, including the electrical properties of water which occurs as a very thin film on ice grains? The state of our knowledge - or lack thereof - of the scattering properties of snow is well illustrated by the often-reproduced microwave images of Greenland and Antarctica taken by the Electronically Scanned Microwave Radiometer (ESMR) on NOAA-2: the brightness temperature patterns are pronounced, stable, and inexplicable; we don't even know what ground-truth data to collect in the field to attempt a correlation with the observed patterns. Thus a fertile field exists for research, which will eventually allow us to monitor this important element of our environment.

\section{REFERENCES}

Ambach, W., and Denoth, A. 1972. Studies on the dielectric properties of snow. Zeitschrift für Gletscherkunde und Glazialgeologie, Bd. 8, Ht. I-2, p. $113-23$.

Barnes, J. C., and Bowley, C. J. 1968. Operational guide for mapping snow cover from satellite photography. Concord, Mass., Allied Research Associates, Inc. ([Report] 8G48-F.

Barnes, J. C., and Bowley, C. J. 1972. Snow studies using thermal infrared measurements from earth satellites. Baltimore, Md., Allied Research Associates, Inc. (Final Report 8G92-F, Contract No. I-35350.) 
Barnes, J. C., and Bowley, C. J. 1973. Use of ERTS data for mapping snow cover in the western United States. (In Freden, S. C., and others, comp. and ed. Symposium on significant results obtained from the Earth Resources Technology Satellite-I. Vol. 1 : technical presentations, section A. The proceedings of a symposium held by Goddard Space Flight Center at New Carrollton, Maryland, on March 5-9, 1973. Compiled and edited by S. C. Freden, E. P. Mercanti and M. A. Becker. Washington, D.C., Scientific and Technical Information Óffice, National Aeronautics and Space Administration, p. 855-62. (NASA SP-327.))

Barnes, J. C., and others. 1974. A study to develop improved spacecraft snow survey methods using Skylab/EREP data: demonstration of the utility of the $S_{190}$ and $S_{192}$ data, [by] 7. C. Barnes, C. F. Bowley, M. D. Smallwood. Lexington, Mass., Environmental Research and Technology, Inc. (ERT Document 0412-7, Contract No. NAS 9-1 3305.)

Bissell, V. C., and Peck, E. L. 1973. Monitoring snow water equivalent by using natural soil radioactivity. Water Resources Research, Vol. 9, No. 4, p. 885-9o.

Edgerton, A. T., and others. 1971. Microwave radiometric investigations of snowpacks, by A. T. Edgerton, A. Stogryn and G. Poe. El Monte, Calif., Aerojet-General Corporation Microwave Division. (Final Report 1285R-4, Contract No. 14-08-0o I-I 1828.)

England, A. W. 1974. Thermal microwave emission from a halfspace containing scatterers. Radio Science, Vol. 9, No. 4, p. 447-54.

Evans, W. E., and Serebreny, S. M. 1973. Analysis of ERTS imagery using special electronic viewing/measuring equipment. (In Freden, S. C., and others, comp. and ed. Symposium on significant results obtained from the Earth Resources Technology Satellite-I. Vol. 1 : technical presentations, section B. The proceedings of a symposium held by Goddard Space Flight Center at New Carrollton, Maryland, on March 5-9, 1973. Compiled and edited by S. C. Freden, E. P. Mercanti and M. A. Becker. Washington, D.C., Scientific and Technical Information Office, National Aeronautics and Space Administration, p. 121 1-18. (NASA SP-327.))

Fritz, S. 1962. Satellite pictures of the snow-covered Alps during April 1960. Archiv für Meteorologie, Geophysik und Bioklimatologie, Ser. A, Bd. 13, Ht. 2, p. 186-98.

Grasty, R. L., and others. 1974. An experimental gamma-ray spectrometer snow survey over southern Ontario, by R. L. Grasty, H. S. Loijens and H. L. Ferguson. (In Santeford, H. S., and Smith, J. L., comp. Advanced concepts and techniques in the study of snow and ice resources. Washington, D.C., National Academy of Sciences, p. 579-93.)

Kogan, R. M., and others. I965. Opredeleniye vlagozapasov v snezhnom pokrove metodom samoletnoy gamma"'yemki [Determination of water equivalent of snow cover by method of aerial gamma-survey]. [By] R. M. Kogan, M. V. Nikiforov, Sh. D. Friedman, V. P. Chirkov, A. F. Yakovlev. Meteorologiya i Gidrologiya, 1965, No. 4, p. $5^{1-55}$. [English translation in Soviet Hydrology. Selected Papers, 1965, No. 2, p. 183-87.]

Krimmel, R. M., and Meier, M. F. 1975. Glacier applications of ERTS images. Fournal of Glaciology, Vol. 15, No. 73 , p. $391-402$.

Leaf, C. F. 1967. Areal extent of snow cover in relation to streamflow in central Colorado. Proceedings of the International Hydrology Symposium. Fort Collins, Colorado, September 1967. Fort Collins, Colorado, Colorado State University, Vol. 1, p. 157-64.

Linlor, W. I. 1975. Electromagnetic reflection from multi-layered models. Fournal of Glaciology, Vol. 15, No. 73, p. 462 .

Linlor, W. I., and Smith, J. L. 1974. Electronic measurements of snow sample wetness. (In Santeford, H. S., and Smith, J. L., comp. Advanced concepts and techniques in the study of snow and ice resources. Washington, D.C., National Academy of Sciences, p. 720-28.)

Linlor, W. I., and others. 1974. Microwave profiling of snowpack free-water content, by W. I. Linlor, M. F. Meier and J. L. Smith. (In Santeford, H. S., and Smith, J. L., comp. Advanced concepts and techniques in the study of snow and ice resources. Washington, D.C., National Academy of Sciences, p. 729-36.)

McClain, E. P., and Baker, D. R. 1969. Experimental large-scale snow and ice mapping with composite minimum brightness charts. ESSA National Environmental Satellite Center. Technical Memorandum NESCTM 12.

Martinec, J. 1973. Evaluation of air photos for snowmelt-runoff forecasts. (In [International Hydrological Decade.] The role of snow and ice in hydrology. Proceedings of the Banff symposia, September 1972. Paris, UNESCO; Geneva, WMO; Budapest, IAHS, Vol. 2, p. 915-26.)

Meier, M. F. 1973[a]. Evaluation of ERTS imagery for mapping and detection of changes of snowcover on land and on glaciers. (In Freden, S. C., and others, comp. and ed. Symposium on significant results obtained from the Earth Resources Technology Satellite-I. Vol. 1 : technical presentations, section B. The proceedings of a symposium held by Goddard Space Flight Center at New Carrollton, Maryland, on March 5-9, 1973. Compiled and edited by S. C. Freden, E. P. Mercanti and M. A. Becker. Washington, D.C., Scientific and Technical Information Office, National Aeronautics and Space Administration, p. 863-75. (NASA SP-327.))

Meier, M. F. 1973[b]. Measurement of snow cover using passive microwave radiation. (In [International Hydrological Decade.] The role of snow and ice in hydrology. Proceedings of the Banff symposia, September 1972. Paris, UNESCO; Geneva, WMO; Budapest, IAHS, Vol. 1, p. 739-50.)

Meier, M. F. 1974. Evaluate ERTS imagery for mapping and detection of changes of snowcover on land and on glaciers. Greenbelt, Maryland, Goddard Space Flight Center.

Meier, M. F., and Edgerton, A. T. I97I. Microwave emission from snow-a progress report. Proceedings of the seventh International Symposium on Remote Sensing of Environment . . I971. . . Ann Arbor, Willow Run Laboratories, Institute of Science and Technology, University of Michigan, Vol. 2, p. 1155-63.

Meier, M. F., and others. 1966. Multispectral sensing tests at South Cascade Glacier, Washington, by M. F. Meier, R. H. Alexander and W. J. Campbell. Proceedings of the fourth Symposium on Remote Sensing of Environment ... I966. ... Ann Arbor, Willow Run Laboratories, Institute of Science and Technology, University of Michigan, p. $145-59$.

Moore, R. K. 1972. Use of microwaves for snow, freeze-thaw, and soil moisture determination-a needed research program. Lawrence, Kansas, University of Kansas Center for Research, Inc. (CRES Technical Memorandum Ioo-I.) 
Peck, E. L., and others. 1971. Evaluation of snow water equivalent by airborne measurement of passive terrestrial gamma radiation, [by] E. L. Peck and V. C. Bissell, E. B. Jones, D. L. Burge. Water Resources Research, Vol. 7 , No. 5 , p. I $15 \mathrm{I}-59$.

Randolph, P. D., and others. 1973. A network of telemetered profiling isotopic snow gages, by P. D. Randolph, R. A. Coates, E. W. Killian, L. O. Johnson and R. L. Heath. (In [International Hydrological Decade.] The role of snow and ice in hydrology. Proceedings of the Banff symposia, September 1972. Paris, UNESCO; Geneva, WMO; Budapest, IAHS, Vol. 1, p. 688-701.)

Schmugge, T., and others. 1974. Microwave signatures of snow and fresh water ice, by T. Schmugge, T. T. Wilheit, P. Gloersen, M. F. Meier, D. Frank and I. Dirmhirn. (In Santeford, H. S., and Smith, J. L., comp. Advanced concepts and techniques in the study of snow and ice resources. Washington, D.C., National Academy of Sciences, p. $55^{1-62 .)}$

Smith, J. L. 1967. Instrumentation for snow gaging - yesterday, today, and tomorrow. Isotopes and Radiation Technology, Vol. 4, No. 3, p. 227-37.

Stogryn, A. 1970. The brightness temperature of a vertically structured medium. Radio Science, Vol. 5, No. 12, p. $1397-1406$.

Strong, A. E., and others. I97 I. Detection of thawing snow and ice packs through the combined use of visible and near-infrared measurements from Earth satellites, [by] A. E. Strong, E. P. McClain and D. F. McGinnis. Monthly Weather Review, Vol. 99, No. 1 1, p. 828-30.

Vickers, R. S. 1971. The measurement of snow depth and density using a short pulse radar system. Colorado State University. Dept. of Electrical Engineering. Report I4-06-D-7 I 59- I.

Waite, W. P., and MacDonald, H. C. 1970. Snowfield mapping with K-band radar. Remote Sensing of Environment, Vol. 1, No. 2, p. 143-50.

Watson, K., and others. 1971. Application of thermal modeling in the geologic interpretation of IR images, by K. Watson, L. C. Rowan, and T. W. Offield. Proceedings of the seventh International Symposium on Remote Sensing of Environment ... I97I. ... Ann Arbor, Willow Run Laboratories, Institute of Science and Technology, University of Michigan, Vol. 3, p. 291 7-41.

\section{DISCUSSION}

P. Gloersen: What was the wavelength of the radar used to image Mt Rainier (Fig. 6)?

M. F. MeIER: K-band, I believe.

Gloersen: The lack of back-scatter from large parts of the snow field at this wavelength $(\lambda=0.8 \mathrm{~cm})$ is surprising.

D. F. PAGE: In this image showing a bright return from the top of Mt Rainier, was this area of the mountain covered with old, perennial snow?

MeIER: Yes, and also at intermediate altitudes.

R. T. Lowry: Were you implying that the bright peak of Mt Rainier was snow or merely reflection from a rough surface perpendicular to the beam of the radar?

MeIER: Not necessarily. I was simply pointing out the difficulty of determining snow cover from SLAR.

V. Kolar: You said you had not been able to reproduce your experiment because of complications. What were they?

MeIer: The emission depends on many factors. We held all factors constant except the mass of the snow pack. In a real snow pack you have scattering, layering, etc., which creates complications.

J. Martinec: You mentioned the interference of clouds in evaluating the snow cover. Would it not be possible to use the $2 \mu \mathrm{m}$ band in order to distinguish between them? It seems that snow appears dark at this wavelength while clouds are white.

Meier: There are some difficulties. During Skylab we found that, in some near-IR bands, melting snow surfaces were darker than clouds, but cold snow surfaces were not.

R. S. Williams, JR: What map scales do you usually work with on the ERTS imagery, and what is the maximum map scale you can use with ERTS imagery and still retain confidence in the data (resolution of data versus mapping scale)?

MeIER: R. Krimmel will discuss this later in presenting Krimmel and Meier (1975). We can map snow cover in basins down to $6 \mathrm{~km}^{2}$ in size with confidence. In one case we were able to clearly identify a snow patch with known dimensions of $150 \mathrm{~m}$. 